\title{
THE IMPACT OF CREDIT ACCESS AND COOPERATIVE MEMBERSHIP ON FOOD SECURITY OF RURAL HOUSEHOLDS IN SOUTH-WESTERN NIGERIA
}

\author{
Ayodeji Damilola Kehinde $^{\natural}$, Mary Adedolapo Kehinde $^{1}$ \\ Obafemi Awolowo University, Nigeria
}

\begin{abstract}
This study investigated the impact of credit access and cooperative membership on food security of rural households in south-western Nigeria. A multistage sampling procedure was employed to select 300 rural households for the study. Data were analysed using a food security index, binary logit model, propensity score matching (PSM) and augmented inverse-probability weighting model (AIPW). The binary logit estimates revealed that age, household size, years of education, farm size, farm income and non-farm income significantly influenced the likelihood of rural households being members of cooperatives while household size, years of education, farm size, gender, household assets and farm income significantly influenced the likelihood of rural households' access to credit. The food security index revealed that $66 \%$ of households were food insecure. PSM revealed that cooperative membership and credit access are expected to increase the food security of rural households by approximately 1,446 and 1,496 kilocalories per person per day, respectively. AIPW revealed that cooperative membership and credit access are expected to increase the food security of rural households by approximately 1,888 and 1,899 kilocalories per person per day, respectively. The study concluded that both credit access and cooperative membership have a positive and significant impact on food security of rural households. Thus, any programmes targeted at ensuring rural households' food security, particularly in south-western Nigeria, should take cognisance of their credit access and cooperative membership.
\end{abstract}

Keywords: credit access, cooperative membership, food security, rural households, south-western Nigeria

\section{INTRODUCTION}

Food security is a situation when all people have physical, social and economic access to sufficient, safe and nutritious food, at all time, to maintain a healthy and active life (Duffour, 2011; FAO, 2008; 2012). This definition introduces the basic concepts of food security and enlists three key steps of achieving food security (FAO, 2013). And those are food availability, food accessibility, and food utilisation. The first concept, namely food availability, implies a self-sufficiency of the household. It refers to the capacity or ability of the household to have nutritious food in sufficient quantities, continuously and consistently, either through local production or purchases. Food access is the ability of the household to have economic and physical access to nutritious food in the right quantities to meet nutritional requirements of the household members. Food utilisation is the consumption of nutritious food that meets the macro- and micronutrient requirements of individuals in the household. From the foregoing, it is evident that food security may not be achieved, if individuals' access to food is not adequately addressed. This underlines the fact that physical and economic access of individuals to food is important in combating the issue of food insecurity (FAO, 2010).

However, individuals in a household enjoy food security when the household is food secured. This is

\footnotetext{
$\bowtie$ Ayodeji Damilola Kehinde, Department of Agricultural Economics, Obafemi Awolowo University, Ile Ife, 220005 Osun State, Nigeria, e-mail: kehindeayodeji8@gmail.com; https://orcid.org/0000-0003-1931-6542
} 
Kehinde, A. D., Kehinde, M. A. (2020). The impact of credit access and cooperative membership on food security of rural households in south-western Nigeria. J. Agribus. Rural Dev., 3(57), 255-268. http://dx.doi.org/10.17306/J.JARD.2020.01337

because food security is a measure of a household's condition, not that of individuals in a household. At the household level, food security implies adequate access to food at all time (Fawehinmi and Adeniyi, 2014). However, household food insecurity remains a fundamental challenge in Nigeria. Over $70 \%$ of the population is still living on less than a dollar per day and over $50 \%$ is food insecure, while the majority consume less than their dietary requirements (Babatunde et al., 2008; Ibok, 2012). In a similar vein, estimates by Orewa and Iyangbe (2010); Akerele et al. (2013), and Olawale (2018) show that over 53 million, i.e. about $30 \%$ of the people in Nigeria, are hungry and $52 \%$ live below the poverty line. Moreover, the problem of food insecurity is far more pronounced among rural households. Over $70 \%$ of rural households in south-western Nigeria are food insecure (Babatunde et al., 2007; Oxfam, 2012; Adeniyi and Ojo, 2013; Oluyole and Taiwo, 2016). Several factors such as age, household size, or lack of credit access expose rural households to food insecurity. However, notable among the factors is lack of sufficient income (Odemenem and Obinne 2010). Rural people are mostly subsistence farmers and proceeds from farms are barely enough to sustain their family needs. This has serious negative consequences on households' overall welfare, including food security (Diagne and Zeller, 2001; Chikaire et al., 2015).

Credit support of the households could serve as a policy tool for alleviating the food insecurity. Credit allows poor households to engage in income-generating activities and investments to improve their livelihoods (Ijaiya and Abdulraheem, 2000). Efforts have been made by the government to deliver credit services to rural households through a number of programmes (Ugbajah and Ugwumba, 2013), among these efforts is the establishment of cooperatives. Cooperatives play a key role in tackling rural poverty and increasing food security (Shiferaw et al., 2014; Zeng et al., 2015). Rural households with low income pull their resources together to form cooperatives in order to generate more income. Cooperatives pool different resources such as credit, information and labour among members to achieve mass production and purchase food or satisfy other basic needs of its members (Tefera et al., 2016). Hence, they play an important role in supporting long-term food security (Lecoutere, 2017). However, several empirical studies on cooperative membership and credit access have focused on farm productivity, technology adoption, technical efficiency commercialisation and poverty reduction (Francesconi and Ruben, 2012; Abebaw and Haile, 2013; Abate et al., 2014; Verhofstadt and Maertens, 2015). Whereas, cooperative membership and credit access could improve the food security of rural households through relaxing liquidity constraint facing the households.

Therefore, more research is essential to reveal the simultaneous impact of credit access and cooperative membership on food security. There is limited empirical research on the simultaneous impact of credit access and cooperative membership on food security of rural households, particularly in Nigeria. This study fills this literature gap. The objective of this study is threefold. Firstly, it aims to identify the major determinants of access to credit and membership of cooperatives; secondly, to estimate the rural households' food security; and thirdly, to examine the impact of credit access and cooperative membership on rural households' food security.

\section{RESEARCH METHODOLOGY}

\section{Studied area}

This study was carried out in the south-western part of Nigeria, which represents the geographical area between latitude $6^{\circ} 21^{\prime} \mathrm{N}$ and $8^{\circ} 37^{\prime} \mathrm{N}$ and longitude $2^{\circ} 31^{\prime} \mathrm{E}$ and $6^{\circ} 00^{\prime} \mathrm{E}$. The region is bounded in the north by Kogi and Kwara States, in the south by the Atlantic Ocean, in the west the Republic of Benin and in the east by Edo and Delta States. The total population is about 27,581,992. It is majorly a Yoruba speaking area, although there are different dialects even within one state. It is characterised by two climatic seasons: rainy and dry season. The rainy or wet season lasts from March to October, while the dry season, which is shorter, lasts from November to March. The temperature ranges between $21^{\circ} \mathrm{C}$ and $34^{\circ} \mathrm{C}$ while the annual rainfall ranges between $1,500 \mathrm{~mm}$ and $3,000 \mathrm{~mm}$. The favourable climatic and soil condition of the area encouraged about $70 \%$ of the inhabitants to engage in farming. Farmers grow both permanent and food crops. The climate is ideal for the cultivation of crops like maize, yam, cassava, millet, rice, plantain, cashew and cocoa.

\section{Sampling technique and sample size}

A multistage sampling procedure was employed to select respondents for this study. The first stage involved a simple random selection of two (2) states (Osun and 


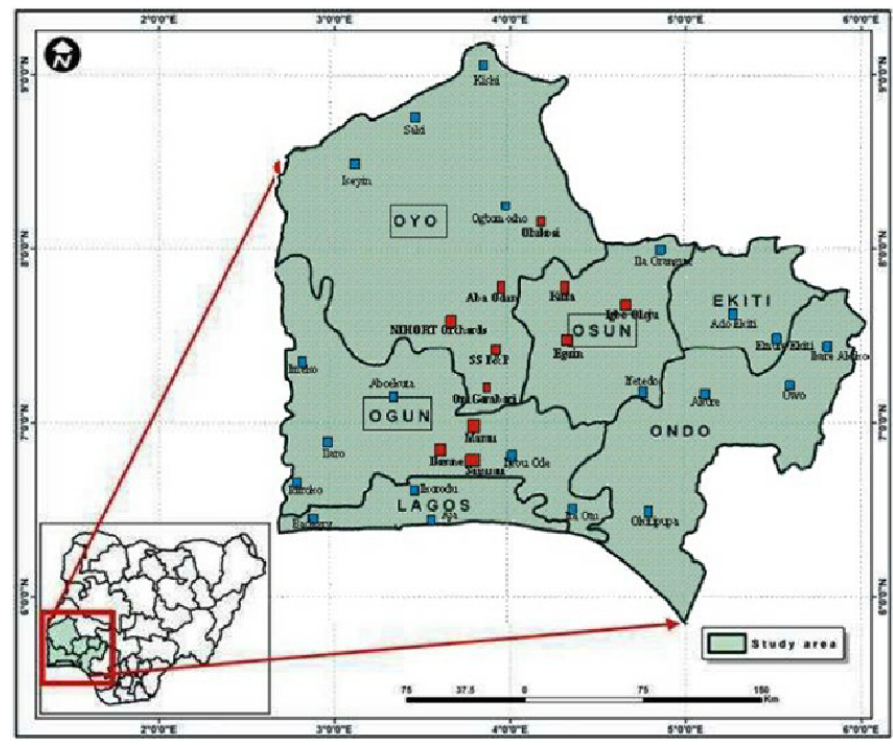

Fig. 1. Map of south-western Nigeria

Source: Google map, 2019.

Ondo) out of six (6) states in south-western Nigeria using paper balloting without replacement. The second stage involved a simple random selection of three (3) local government areas (LGAs) from each selected state. In Osun State, Atakumosa East, Atakumosa West and Ife North LGAs were selected while, Ondo West, Idanre and Ile Oluji/Okeigbo LGAs were selected in Ondo State. The third stage was the simple random selection of five (5) villages in each LGA. The fourth stage involved a simple random selection of ten rural households in each village. A total of 300 households were selected for the study (Table 1).

Table 1. Sampling procedure for the study

\begin{tabular}{clcc}
\hline State & \multicolumn{1}{c}{ LGA } & Villages & Rural households \\
\hline Osun & Atakumosa East & 5 & 10 \\
& Atakunmosa West & 5 & 10 \\
& Ife North & 5 & 10 \\
\multirow{2}{*}{ Ondo } & Ondo West & 5 & 10 \\
& Idanre & 5 & 10 \\
\multirow{2}{*}{ Total } & Ile Oluji/Okeigbo & 5 & 10 \\
\hline
\end{tabular}

\section{Analytical techniques and model specification}

Firstly, data were analysed using descriptive statistics in order to describe socio-economic characteristics of the rural households. Data were also analysed using a food security index, binary logit model, propensity score matching (PSM) and augmented inverse-probability weighting model (AIPW).

\section{Food security index}

Calorie consumption was used as a proxy for measuring food security. A calorie-consumption model was specified and estimated for 2018 cropping season. Consumption is made up of household's produced and purchased food. Data on the consumption quantity (in $\mathrm{kg}$ ) of various foodstuffs by each household per month were obtained and converted into energy intake ( $\mathrm{kcal} / \mathrm{kg}$ ) using the information in Table 2.

Following Adeniyi and Ojo (2013), all household members' calorie intake was converted into adult equivalent using the formula given below:

$$
\mathrm{ADEQ}=(\mathrm{A}+0.5 \mathrm{C})^{0.9}
$$

where:

ADEQ - adult equivalent units

$\mathrm{A}-$ number of adults ( 15 years and above) 
Table 2. Foodstuff equivalent conversion ratios

\begin{tabular}{lc}
\hline \multicolumn{1}{c}{ Foodstuff } & Energy $(\mathrm{kcal} / \mathrm{kg})$ \\
\hline Maize & 3,600 \\
Rice & 3,500 \\
Millet \& Sorghum & 3,500 \\
Cowpea & 3,300 \\
Groundnut & 5,500 \\
Soybean & 4,000 \\
Cassava (fresh) & 1,500 \\
Cassava (flour) & 3,400 \\
Yam (flesh) & 1,100 \\
Yam (flour) & 3,200 \\
Beef & 6.25 \\
Wheat & 3,330 \\
Leaf vegetable & 3.87 \\
Legume average & 2.6 \\
Sweet potatoes & 970 \\
\hline
\end{tabular}

Source: FAO, 2013 - food consumption tables for international conversion: www.fao.org/docrep/x557e/x5557404.htm.
$\mathrm{C}$ - number of children in a household (below the age of 15 years).

Following FAO $(2005 ; 2013)$ and Adeniyi and Ojo (2013), a food security index was constructed based on the daily calorie intake $(2,850 \mathrm{kcal} / \mathrm{day})$ recommended by the FAO, after the conversion of all household members' calorie intake into adult equivalence. In constructing the food security index, the minimum level of nutrition necessary to maintain a healthy living was identified. The safe minimum daily energy intake should not be below $80 \%$ of the above calorie requirement. In this regard, the minimum energy intake should be about $2,280 \mathrm{kcal}$ per adult equivalent per day. This defines the food security line for the study. Households with a daily per capita calorie intake of 2,280 kcal and above were regarded as food secure, while those with a smaller intake were regarded as food insecure.

Following Fakiyesi (2001) and Adeniyi and Ojo (2013), the food security (Z) index which could either equal to 0 or 1 was calculated as follow:

$$
Z_{n}=\frac{Y_{n}}{R}
$$

where:

$Y_{n}-$ is the $n^{\text {th }}$ household's daily per capita calorie intake

$R$ - is the recommended per capita daily calorie intake $(2,850 \mathrm{kcal} / \mathrm{day})$.

$Z_{n}=1$ for $Y_{n} \geq 1$ (i.e. food secure households) and $Z_{n}=0$ for $Y_{n} \leq 1$ (i.e. food insecure households)

If $Z_{n}$ is 1 , the households are food secure, while $Z_{n}=0$, if otherwise.

Following Adeniyi and Ojo (2013), the depth of food insecurity was calculated using the following formulae:

$$
\mathrm{FIG}_{\mathrm{n}}=\frac{\mathrm{TCR}_{\mathrm{n}}-\mathrm{TCC}_{\mathrm{n}}}{\mathrm{TCR}_{\mathrm{n}}}
$$

Where FIG $_{n}$ is the food insecurity gap of the nth household, $\mathrm{TCR}_{\mathrm{n}}$ is the total calorie requirement for the nth insecure household and TCCn is the total calorie consumed by the nth insecure household.

and

$$
\mathrm{TCR}_{\mathrm{n}}=R \times \mathrm{ADEQ}
$$

$$
\mathrm{TCC}_{\mathrm{n}}=Y_{n} \times \mathrm{ADEQ}
$$

The head count ratio $(H)$ is the fraction of the population that is food insecure and it was calculated as:

$$
H=\frac{M}{N}
$$

where:

$M$ - is the number of food insecure households

$N-$ is the sample population.

Based on $H$, other food security measures were calculated for food insecure households.

Therefore, the total food insecurity gap was calculated as:

$$
\mathrm{MFIG}=\Sigma_{i}^{n} \frac{\mathrm{FIG}_{\mathrm{i}}}{\mathrm{N}}
$$

where:

MFIG - mean food insecurity gap, which indicates the depth of food insecurity among the food insecure households

$\mathrm{N}$ - number of food insecure households.

Following Idrisa et al. (2008) and Adeniyi and Ojo (2013), the severity of food insecurity was calculated as: 


$$
\mathrm{SFIG}=\sum_{i}^{n} \frac{\left(\mathrm{FIG}_{\mathrm{i}}\right)^{2}}{N}
$$

where SFIG - is severity of food insecurity.

\section{Binary logit regression model}

The binary logit regression model was used to determine the factors influencing access to credit and cooperative membership among rural households. The model was adopted for this study because it permits the analysis of decisions across two categories in the dependent variable. Hence, it makes it possible to determine choice probabilities for access to credit and cooperative membership among rural households. For instance, 1 denotes credit access/cooperative membership and 0 denotes otherwise.

Therefore, the binary logit model for this study is specified as follows:

where:

$$
Y^{*}=\beta_{0}+\beta_{i} X_{i}+\mu_{i}
$$

$$
\begin{aligned}
& Y^{*}-\text { dependent variable } \\
& X_{i} \text { - explanatory variable } \\
& \beta \text { - coefficient to be estimated } \\
& \mu_{i} \text {-random disturbance term. }
\end{aligned}
$$

The dependent variable in this regression equation is the logarithm of the odds that a particular choice will be made.

In this regard,

$$
\ln \left(\frac{P(x)}{1-P(x)}\right)=\beta_{i 0}+\mathrm{x} . \beta_{0}
$$

Therefore

$\ln \left(\frac{P(x)}{1-P(x)}\right)=1$, if the rural households have access

to credit / are members of cooperatives

$\ln \left(\frac{P(x)}{1-P(x)}\right)=0$, if the rural households do not have access to credit / are not members of cooperatives.

The marginal effect of the variables is calculated using the following formula:

$$
\text { Marginal effects }=\beta_{i} \varnothing(z)
$$

where:

$\beta_{i}-$ are the coefficients of the variables

$\emptyset(z)$ - are the cumulative normal distribution value associated with the mean dependent variable from the probit estimation.
The model is empirically estimated as follows:

$$
\begin{gathered}
Y^{*}=\beta_{0}+\beta_{1} X_{1}+\beta_{2} X_{2}+\beta_{3} X_{3}+\beta_{4} X_{4}+ \\
\beta_{5} X_{5}+\ldots \beta_{11} X_{11}+\varepsilon_{i}
\end{gathered}
$$

$Y$ - access to credit/cooperative membership $(1=$ yes, $0=$ otherwise)

The explanatory variables are: $X_{1}-$ age of farmers (years); $X_{2}$ - age square of farmers (a representation of old age) (years); $X_{3}$ - household size (actual number); $X_{4}$ - education (years spent in formal education); $X_{5}$ - farm experience (years); $X_{6}$ - farm size (ha); $X_{7}$ - gender of the farmer (male $=1$, female $=0) ; X_{8}$ - value of household asset (Naira); $X_{9}$ - income from farming (NGN); $X_{10}$ - income from other source $(\mathrm{NGN}) ; X_{11}-$ access to extension services $(1=$ yes, $0=$ otherwise $)$.

\section{Propensity score matching and augmented inverse-probability weighting model}

The mean outcomes of two groups considered in this study might differ, even in the absence of the treatment, due to some unobservable factors. There might be selfselection bias in sorting respondents into access and no access to credit/members and non-members of cooperative based on the observable differences. In order to avoid initial selection bias, comparability in their socioeconomic endowment must be established before proceeding to future counterfactuals. Following Caliendo and Kopeinig (2008) and Ahmed and Mesfin (2017), the study employed a PSM model to deal with the problem of selection bias. The model adjusts the differences between treatment and control group by matching each member unit to a non-member unit based on similar observable characteristics and by conveniently summarising the conditional probability of member given pretreatment characteristics (Rosenbaum and Rubin, 1983).

The first step in the PSM model is predicting the propensity score using a logit model. The model is expressed as follows:

$$
p_{i}=\frac{e^{z_{i}}}{1+e^{z_{i}}}
$$

where:

$p_{i}$ - is the probability of having access to credit or being a member of cooperative society

$e$-represents the base of natural logarithms

$z_{i}$ - represents the $n$ function of the explanatory variables which can also be expressed as 


$$
Z^{*}=\beta_{0}+\beta_{i} X_{i}+v_{i}
$$

where:

$$
\begin{aligned}
& i-1,2,3 \ldots \ldots n \\
& \beta_{0}-\text { is intercept } \\
& \beta_{i}-\text { is regression coefficient to be estimated } \\
& V_{i}-\text { is the disturbance term } \\
& X_{i}-\text { is a set of observable characteristics. }
\end{aligned}
$$

The second step is imposing the common support region. The average treatment effect on treated group and on population should only be defined in this region (Caliendo and Kopeinig, 2008; Ahmed and Mesfin, 2017). The common support region is the area within the minimum and maximum propensity scores of treated and control groups, respectively. It is demarcated by cutting off those observations whose propensity scores are smaller than the minimum of the treated group and greater than the maximum of the comparison groups (Caliendo and Kopeinig, 2008). Then, the next stage is identification of an appropriate matching estimator. The impact of credit access and cooperative membership on food security of rural households was determined using Kernel matching based on common support. Checking for matching quality follows this stage to determine whether the matching procedure can balance the distribution of different variables or not. If a good match is found with the predicted probabilities of participation of households in cooperatives and accessing credit, the impact of the treatment on the outcome is determined.

Following Bellemare and Novak (2017) and Wooldridge (2010), it is assumed that the outcome model is represented by a linear regression function as follows:

$$
Y_{i}=\beta_{0}+\beta_{1} X_{i}+\beta_{2} Z_{i}+\mu_{i}
$$

where:

$Y_{i}-$ is a daily calorie intake

$X_{i}-$ is a set of control variables

$Z_{i}$ - indicates whether an individual had access to credit or not/is a member or non-member of cooperative

$\mu_{i}-$ is the error term.

The average treatment effect on the treated (ATT) is given by the difference in mean outcome of matched members and non-members that have common support conditional on the propensity score. The mean impacts of cooperative membership/credit access will, therefore, be given by:

$$
\tau_{i}=Y\left(D_{i}=1\right)-Y\left(D_{i}=0\right)
$$

where:

$\tau_{i}-$ is the treatment effect

$Y_{i}$ - is the outcome

$D_{i}$ - is a dummy whether $n^{\text {th }}$ household has received the treatment or not.

However, $Y\left(D_{i}=1\right)$ and $Y\left(D_{i}=0\right)$ cannot be observed for the same household at the same time. Due to this fact, estimating individual treatment effect $\tau_{i}$ is not possible and one has to shift to estimating the average treatment effects of the population rather than the individual one.

The average treatment effect on the treated is specified as:

$$
\begin{gathered}
\tau_{A T T}=E(I \mid D=1)=E[Y(1) \mid D=1]- \\
E[Y(0) \mid D=1]
\end{gathered}
$$

As the counterfactual mean for those being treated, $E[Y(0) \mid D=1]$ is not observed, one has to choose a proper substitute for it in order to estimate the ATT. By rearranging and subtracting $E[Y(0) \mid D=0]$ from both sides, one can get the following specification for ATT:

$$
\begin{gathered}
E[Y(1) \mid D=1]-E[Y(0) \mid D=1]-E[Y(0) \mid D=0] \\
=\tau_{A T T}+E(Y(0) \mid D=1)-E[Y(0) \mid D=0]
\end{gathered}
$$

Both terms on the left-hand side are observable, and ATT can be identified, if and only if $E[Y(0) \mid D=1-E[Y(0)$ $\mid D=0]=0]$, i.e. when there is no self-selection bias. If there is selection bias, then matching estimators are not robust (Rosenbaum, 2002).

To address this issue, following the work of Abebaw and Haile (2013), Ahmed and Mesfin (2017), we builtin numerous covariates in the logit model to reduce bias, which could appear due to omitted variables.

Secondly, we checked the sensitivity of the estimates to hidden bias, following the Rosenbaum (2002) approach. The Rosenbaum sensitivity test was used to resolve the issue of hidden bias due to unobserved factors using the KBM Hodges-Lehmann point estimates, specified as follows:

$$
\frac{1}{\Gamma} \leq \frac{\pi j /(1-\pi j)}{\pi k /(1-\pi k)} \leq \Gamma
$$

However, the ATT from PSM can still produce biased estimates in the presence of misspecification (Robins et al., 2007; Wooldridge, 2010). We also implemented the AIPW model to check the consistency of the PSM result 
to control any selection bias. The AIPW estimator has a property of double robustness that will present consistent estimates in the presence of misspecification in the treatment/outcome model.

The ATT is then computed as follows:

$$
A T T=\frac{1}{N_{w}} \sum_{i}^{N_{w}}\left[\left(\beta_{1}-\beta_{0}\right)-\left(\alpha_{1}-\alpha_{0}\right) X_{i}\right]
$$

where:

$\beta_{1}$ and $\alpha_{1}-$ are estimated inverse probability weighted parameters for treated households

$\beta_{0}$ and $\alpha_{0}-$ are estimated inverse probability weighted parameters for untreated households

$N_{w}$-stands for the total number of treated households.

\section{RESULTS AND DISCUSSION}

\section{Socioeconomic characteristics of rural households}

Socio-economic characteristics of rural households are presented in Table 3. The majority (89\%) of household heads were males. This implies that households in south-western Nigeria are dominated by male-headed households. The mean age of the household heads is approximately 51 years. In this case, it can be confirmed that household heads are within the working age of 15 to

Table 3. Socio-economic characteristics of rural households

\begin{tabular}{lc}
\hline \multicolumn{1}{c}{ Variables } & Rural households \\
\hline Age & $51(19.48)$ \\
Household size & $7.05(2.12)$ \\
Years of education & $8.86(4.38)$ \\
Years of farming experience & $23.98(19.25)$ \\
Farm size & $10.686(8.89)$ \\
Gender (male) (\%) & 89 \\
Household assets & $925,76(78,612)$ \\
Farm income & $373,714(201,373)$ \\
Non-farm income & $107,429(103,219)$ \\
Access to extension services (\%) & 85 \\
Credit access (\%) & 80.67 \\
Cooperative membership (\%) & 67 \\
\hline
\end{tabular}

*The figures in parenthesis () are standard deviations. Source: field survey, 2018.
64 years. This implies that they are capable of working and earning a living to cater for household's needs. The mean household size is approximately 7 persons.

This implies that the household is large enough to increase the number of consumers, thereby putting pressure on household's resources particularly food. This result is consistent with the findings of Ibok (2012). The mean of years of education of the household heads is approximately 9 years. This indicates a high level of literacy among rural households in south-western Nigeria. This could enhance their ability for budgeting, saving, and conserving households' resources. This result is consistent with the findings of Estruk and Oren (2014). The mean of years of experience of the household heads is approximately 24 years. This implies that the household heads have many years of experience in their professions. This could enable them to prudently use their households' resources. The mean farm size of the household is approximately 11 ha. Farming is a predominant occupation in south-western Nigeria. Therefore, a large farm size would encourage food production and consequently improve their food security. The mean value of the households' assets is approximately 92,576. The value of households' asset indicates its resource endowment and it is a good indicator of households' economic well-being. The households can easily fall back on it in times of food crisis or need by selling or leasing them. This result is in line with the findings of Crepon et al. (2014). The mean annual farm income of the household is approximately 373,714 . The mean annual non-farm income of the household is approximately 107,429. This implies that the annual income of the households is low. This suggests that the food consumption of the household may likely be constrained by limited access to external funds. This result is in line with the findings of Odemenem and Obinne (2010). About $85 \%$ of the household heads in south-western Nigeria have access to extension services. About $67 \%$ of the household heads are members of cooperatives. This implies that a large number of the rural households have access to extension services and membership of cooperative societies. The majority (81\%) of household heads have access to credit.

\section{Determinants of credit access and cooperative membership among rural households}

The determinants of credit access and cooperative membership among rural households are presented in Table 4 . 
Kehinde, A. D., Kehinde, M. A. (2020). The impact of credit access and cooperative membership on food security of rural households in south-western Nigeria. J. Agribus. Rural Dev., 3(57), 255-268. http://dx.doi.org/10.17306/J.JARD.2020.01337

Table 4. Determinants of credit access and cooperative membership among rural households

\begin{tabular}{|c|c|c|c|c|}
\hline \multirow{2}{*}{ Variables } & \multicolumn{2}{|c|}{ Cooperative membership } & \multicolumn{2}{|c|}{ Access to credit } \\
\hline & Coefficient (Z) & Marginal effect & Coefficient (Z) & Marginal effect \\
\hline Age & $-0.198 * *(-2.49)$ & 0.036 & $0.006(0.50)$ & 0.007 \\
\hline $\mathrm{Age}^{2}$ & $0.016(0.82)$ & 0.009 & $0.101(0.76)$ & 0.001 \\
\hline Household size & $0.487 * * *(4.06)$ & 0.008 & $-0.184 * *(-2.19)$ & 0.019 \\
\hline Education & $0.069 *(1.68)$ & 0.012 & $0.145 * * *(3.16)$ & 0.015 \\
\hline Experience & $0.011(0.54)$ & 0.002 & $0.173(0.83)$ & 0.001 \\
\hline Farm size & $0.102 * * *(3.62)$ & 0.018 & $0.143 * * *(3.88)$ & 0.016 \\
\hline Gender & $0.377(0.65)$ & 0.063 & $1.908 * * *(3.62)$ & 0.328 \\
\hline Household assets & $0.025(0.07)$ & 0.004 & $0.602 * *(2.60)$ & 0.072 \\
\hline Farm income & $-0.246 * * *(-3.47)$ & 0.048 & $-1.066 * *(-2.10)$ & 0.112 \\
\hline Non-farm income & $-0.318 * *(-2.26)$ & 0.058 & $1.946(1.27)$ & 0.025 \\
\hline Access to extension services & $0.528(1.28)$ & 0.104 & $0.501(0.93)$ & 0.046 \\
\hline Constant & $4.698 * *(2.38)$ & & $4.577 * *(2.18)$ & \\
\hline $\operatorname{LRchi}^{2}(11)$ & 137.45 & & 166.25 & \\
\hline Prob $>\mathrm{Chi}^{2}$ & 0.000 & & 0.000 & \\
\hline Log likelihood & -121.527 & & -144.183 & \\
\hline Pseudo $\mathrm{R}^{2}$ & 0.3612 & & 0.2249 & \\
\hline
\end{tabular}

***,** and* represent significant levels at $1 \%, 5 \%$ and $10 \%$, respectively. The figures in parenthesis () are $Z$ value.

Source: field survey, 2018

The LR-chi ${ }^{2}$ indicates the overall significance of the models. This implies that there is about $99.99 \%$ assurance that the models were not misspecified. The results of the determinants of cooperative membership show that age, household size, years of education, farm size, farm income and non-farm income significantly influenced the likelihood of rural households being members of cooperatives. The coefficients of household size, years of education and farm size have positive signs. This implies that increase in any of these variables may increase the likelihood of rural households being members of cooperatives. The plausible reason for a positive relationship between years of education and cooperative membership is that education enhances the ability of the household members to know the benefits of joining a cooperative society. This is in agreement with the studies by Chagwiza et al. (2016) and Wossen et al. (2017) that educated people are more motivated to join cooperative societies. The explanation for a positive effect of household size on cooperative membership might be that consumption pressure associated with large households might push the household members to join a cooperative society. This result is in accordance with the studies by Verhofstadt and Maertens (2015) and Ma et al. (2018) that members of large households are likely to be members of cooperative societies. The drive to utilise and maximise the resources on large farms might motivate household members to join a cooperative society. The result is in line with the studies by Ma and Abdulai (2016); Mojo et al. (2017) Wossen et al. (2017), Ma et al. (2018) that household members with large farms are likely to be members of cooperatives societies.

However, coefficients of age, farm income and nonfarm income have negative signs. This implies that an increase in any of these variables may decrease the likelihood of rural households being members of cooperatives. The explanation for a negative effect of age on cooperative membership might be that young rural household heads are always strong enough to work or 
invest in the income-generating activities; however, they do not have funds to invest efficiently. In order to raise funds for initial investment, they might be encouraged to join cooperative societies. Rural households with a substantial amount of income flow (farm and non-farm) may not join cooperative societies. This can be ascribed to the fact that a substantial amount of income flow increases the financial security of households as well as relaxes their liquidity constraints. In this regard, the household members may not have a reason to join cooperative societies. This result is not congruent with the existing studies such as Abebaw and Haile (2013) who suggest that an increase in income increases cooperative membership among rural households.

The results of the determinants of credit access show that household size, years of education, farm size, gender, assets and farm income significantly influenced the likelihood of rural households' access to credit. The coefficients of years of education, farm size, gender and households' assets have positive signs. This implies that an increase in any of these variables may increase the likelihood of rural households accessing credit. The possible reason for a positive relationship between years of education and credit access is that education helps household members to make informed decision about credit. This result is in line with the studies by Okuru et al. (2006); Ibrahim and Aliero (2012); Essien et al. (2013) and Duniya and Adinah (2015) who found that education increases credit access. The explanation for a positive relationship between farm size and credit access is that financial requirements for maximising resource on large farms might push the household heads to apply for credit. This result corroborates the findings of Okurut et al. (2006); Sebopetji and Belete (2009); Khan and Hussain (2011); Akudugu (2012) and Akpan (2013) that farm size has a positive effect on access to credit. The possible explanation for the gender and credit access relationship is that male-headed households are much more likely to be endowed with some resources which could serve as collateral for accessing credit. The result agrees with the findings of Alao et al. (2020) that men have better access to credit than women. However, it disagrees with the findings of Ololade and Olagunju (2013) that women are more likely to access credit than men. The plausible explanation for household assets and credit access relationship is that household assets are usually used as a proxy for household wealth which could serve as collateral for assessing external funds.
However, coefficients of household size and farm income have negative signs. This implies that an increase in any of these variables may decrease the likelihood of rural households accessing credit. The possible explanation for a negative relationship between household size and credit access is that household members are working and contributing to household income. As such the household may not necessarily access external funds. This result does not corroborate the findings of Nuryartono, (2007) and Oyedele et al. (2009). Rural households with a substantial amount of farm income may not access external funds. The reason being that a substantial amount of income flow increases the financial security of households as well as relaxes their liquidity constraints. The result agrees with the findings of Mohamen (2003) and Nwaru et al. (2011).

\section{Food security status of rural households}

The food security status of rural households is presented in Table 5 . The average per capita calorie daily intake is 1,918 kilocalories per person per day. This is far lower than the minimum requirement of 2,280 kilocalories per person per day recommended by FAO. About $66 \%$ of households fell below the food security line. The depth of food insecurity indicates that the households are $51.7 \%$ below the food security line. This implies that the food insecure households require $52 \%$ of the value of the food security line to improve their food security status. And the problem of food security was severe in $33.8 \%$ of households. This indicates a serious problem of food insecurity among rural households. This result agrees with Ibok (2012); Adeniyi and Ojo (2013); and Oluyole and Taiwo (2016).

Table 5. Food security status among surveyed households

\begin{tabular}{lcc}
\hline \multicolumn{1}{c}{ Food security status } & Frequency & Percentage \\
\hline Food secure & 103 & 34.33 \\
Food insecure & 197 & 65.67 \\
Total & 300 & 100 \\
Mean calorie/day/person & $1,918( \pm 1,250)$ & \\
Food insecurity Depth & 0.517 & \\
Food insecurity Severity & 0.338 & \\
\hline
\end{tabular}

*Figure in parenthesis is standard deviation Source: field survey, 2018. 


\section{IMPACT OF CREDIT ACCESS AND COOPERATIVE MEMBERSHIP ON FOOD SECURITY OF RURAL HOUSEHOLDS}

\section{Covariate balance matching indicators}

The common support condition was imposed and the balancing property was set and satisfied in the entire estimated model. The matching restricts the control sample in order to increase the similarity of the control samples directly compared with treated samples. The restriction was done in order to estimate the impact of credit access and cooperative membership on food security of rural households. The balancing information on the propensity scores is presented in Table 6 . The mean bias and pseudo $\mathrm{R}^{2}$ were low and dropped significantly after matching in credit access and cooperative membership model, respectively. Also, the p-value was insignificant after matching. This implies that the matching of covariate between the two groups was fairly successful.

Table 6. Covariate balance matching indicators

\begin{tabular}{lcccc}
\hline \multicolumn{1}{c}{ Variables } & \multicolumn{2}{c}{ Cooperative membership } & \multicolumn{2}{c}{ Credit access } \\
\hline $\begin{array}{l}\text { Matching } \\
\text { indicators }\end{array}$ & Unmatched & Matched & Unmatched & Matched \\
\hline PsR $^{2}$ & 0.226 & 0.084 & 0.352 & 0.076 \\
LRchi $^{2}$ & 66.56 & 2.38 & 33.80 & 3.02 \\
$\mathrm{P}>$ chi $^{2}$ & 0.000 & 0.885 & 0.000 & 0.734 \\
Mean bias & 30.6 & 5.2 & 35.7 & 20.1 \\
$\begin{array}{l}\% \text { of bias } \\
\text { reduction }\end{array}$ & & 60.4 & & 64.9 \\
\hline
\end{tabular}

Source: field survey, 2018.

\section{Impact of cooperative membership on food security of rural households}

Table 7 reveals the impact of cooperative membership on food security of rural households. The Table shows that cooperative membership has a positive effect on the food security of rural households. The casual effect of cooperative membership on the food security is 1,445.650 kilocalories per person per day. This implies that cooperative membership is expected to increase the food security of rural households by approximately 1,446 kilocalories per person per day. This suggests
Table 7. Impact of cooperative membership on food security of rural households

\begin{tabular}{cccccc}
\hline Sample & Treated & \multicolumn{1}{c}{ Control } & Std error & T-stat & $\Gamma$ \\
\hline Unmatched & $1,781.254$ & $2,196.092$ & 151.848 & & \\
ATT (PSM) & $1,781.254$ & $1,445.650^{* * *}$ & 143.012 & 2.73 & 1.32 \\
ATT (AIPW) & & $1,888.424 * * *$ & 166.298 & 11.36 & \\
\hline
\end{tabular}

$* * *, * *$ and ${ }^{*}$ represent significant levels at $1 \%, 5 \%$ and $10 \%$, respectively.

that being a cooperative member would afford the rural households an opportunity to increase their food security by that amount. Using the KBM Hodges-Lehmann point estimate, the estimates are free of hidden bias. This suggests that the findings were sensitive to possible hidden bias and cooperative membership has a positive treatment effect on food security of rural households. However, AIPW presents more robust results (ATT $=$ 1888.424) compared with that of PSM. This implies that cooperative membership is expected to increase the food security of rural households by approximately 1,888 kilocalories per person per day. This implies that such an amount was lost as a result of rural households not being members of cooperatives. This finding is in line with the results of Gibremichael (2014); Verhofstadt and Maertens (2015); Chagwiza et al. (2016); Wossen et al. (2017) and Ahmed and Mesfin (2017) that cooperatives have capacities to improve the living standard of their members through many pathways and play vital roles in promoting food security of their members.

\section{Impact of credit access on food security of rural households}

Table 8 reveals the impact of credit access on food security of rural households. The Table shows that access to credit has a positive effect on the food security of rural households. The casual effect of access to credit on the food security is $1,495.854 \mathrm{kcal}$ daily per person. This implies that credit access is expected to increase the food security of rural households by approximately 1,496 kilocalories per person per day. And this suggests that access to credit would afford the rural households an opportunity to increase their food security by that amount. Using the KBM Hodges-Lehmann point estimate, the estimates are free of hidden bias. This suggests that the findings were sensitive to possible hidden 
bias and access to credit has a positive treatment effect on food security of rural households. However, AIPW presents more robust results $($ ATT $=1899.187)$ compared with that of PSM. This implies that credit access is expected to increase the food security of rural households by approximately 1,899 kilocalories per person per day. This implies that such an amount was lost as result of rural households' poor access to credit. The result is in line with the findings of Cheng (2006); Bogale and Shimelis (2009); Hazarika and Guha-Khasnobis (2008); Brannen (2010); Hamad et al. (2010), Tasie et al. (2012); Thuita et al. (2013) and Aidoo et al. (2013) that access to credit improves food production and income of rural households, improving the households' food consumption patterns and contributing to the food security of the households.

Table 8. Impact of credit access on food security of rural households

\begin{tabular}{cccccc}
\hline Sample & Treated & Control & Std error & T-stat & $\Gamma$ \\
\hline Unmatched & $1,911.889$ & $1,944.278$ & 183.043 & & \\
ATT (PSM) & $1,911.889$ & $1,495.854 * * *$ & 149.495 & 2.94 & 1.29 \\
ATT (AIPW) & & $1,899.187 * * *$ & 170.821 & 11.12 & \\
\hline
\end{tabular}

$* * *, * *$ and $*$ represents significant levels at $1 \%, 5 \%$ and $10 \%$, respectively.

\section{CONCLUSIONS AND RECOMMENDATIONS}

This study investigated the impact of credit access and cooperative membership on food security of rural households in south-western Nigeria. Data were analysed using a food security index, PSM and AIPW.

The binary logit estimate reveals that age, household size, years of education, farm size, farm income and nonfarm income significantly influenced the likelihood of rural households being members of cooperatives while household size, years of education, farm size, gender, assets and farm income significantly influenced the likelihood of rural households' access to credit. About 66\% of households fell below the food security line. PSM revealed that cooperative membership and credit access are expected to increase the food security of rural households by approximately 1,446 and 1,496 kilocalories per person per day, respectively. AIPW revealed that cooperative membership and credit access are expected to increase the food security of rural households by approximately 1,888 and 1,899 kilocalories per person per day, respectively. The study concludes that both credit access and cooperative membership have a positive and significant impact on food security of rural households. Any programmes targeted at ensuring rural households' food security, particularly in south-western Nigeria should take cognisance of their credit access and cooperative membership. Therefore, the study suggests that a microcredit scheme through rural cooperative societies should be launched to support rural dwellers' activities in Nigeria. However, the microcredit scheme should be simple, flexible and accessible at low interest rates to the households. This will address the problem of rural households' food security in the country. However, education and farm size are central factors to both cooperative membership and credit access. In encouraging rural households to join a cooperative society, strategies like adult education centres to educate rural people on the economic and social benefit of being a member of cooperative, and efficient use of credit should be developed. In addition, the ownership and land transfer practice that are dominated by inheritance and led to land fragmentation should be reviewed. The policy thrust such as the 1978 Land Use Act that discouraged land fragmentation should be sustained while improving food security among rural households.

\section{FUNDING}

This research did not receive any specific grant from funding agencies in the public, commercial, or not-forprofit sectors.

\section{ACKNOWLEDGEMENTS}

We are very grateful to the farmers who sat patiently for hours to provide answers to the questionnaire.

\section{REFERENCES}

Abate, G.T., Francesconi, G.N., Getnet, K., (2014). Impact of agricultural cooperatives on Smallholders' technical efficiency: empirical evidence from Ethiopia. Ann. Public Coop. Econ., 85(2), 257-286. doi: 10.1111/apce.12035

Abebaw, D., Haile, M.G. (2013). The impact of cooperatives on agricultural technology adoption: empirical evidence 
from Ethiopia. Food Policy, 38, 82-91. http://dx.doi. org/10.1016/j.foodpol.2012.10.003

Adeniyi, O.R., Ojo, O.A., (2013). Food Security Status of Rural Farming Households in Iwo, Ayedire and Ayedaade Local Government Areas of Osun State, South-western Nigeria. Afr. J. Food Agric. Nutr. Dev., 13(5), 8209-8223.

Ahmed, M.H., Mesfin, H.M. (2017). The impact of agricultural cooperatives membership on the wellbeing of smallholder farmers: empirical evidence from eastern Ethiopia. Agric. Food Econ. 5(6), 1-20.

Aidoo, R., Mensah, J., Tuffor, T. (2013). Determinants of household food security in the Sekyere-afram plains district of Ghana. $1^{\text {st }}$ Annual International Interdisciplinary Conference AIIC Azores, Portugal.

Akerele, D., Momoh, S., Aromolara, A.B., Oguntona, C.R.B., Shittu, A.M. (2013). Food Insecurity and Coping Strategies in South-West Nigeria. Food Sec., 5, 407-414.

Akpan, S. (2013). Determinants of credit access and demand among poultry farmers in Akwa Ibom State, Nigeria. Am. J. Experi. Agri., 3, 293-307.

Akudugu, M.A. (2012). Estimation of the determinants of credit demand by farmers and supply by rural banks in Ghana's upper east region. Asian J. Agric. Rural Dev., 2, 189-200.

Alao, T.B., Bamire, A.S., Kehinde, A.D. (2020). Gender analysis of agricultural financing in cocoa-based farming system in Oyo and Osun States of South Western Nigeria. Ghana J. Agric. Sci. 55(1), 34-42.

Babatunde, R.O., Omotesho, O.A., Olorunsanya, E.O., Owotoki, G.M. (2008). Determinants of vulnerability to food insecurity: A gender-based analysis of farming households in Nigeria. Indian J. Agric. Econ., 63(1), 1-10.

Babatunde, R.O., Omotosho, O.A., Sholotan, O.S. (2007). Factors influencing food security status of rural farming households in North Central Nigeria. Agric. J., 2(3), 351-357.

Bellemare, M.F., Novak, L. (2017). Contract farming and food security. Am. J. Agric. Econ., 99, 357-378.

Bogale, A., Shimelis, A. (2009). Household level determinants of food security in rural areas of Dire Dawa, Eastern Ethiopia. Afri. J. Food Agric. Nutr. Dev., 9(9), 1914-1926.

Brannen, C., (2010). An impact study of the Village Savings and Loan Association (VSLA) Program in Zanzibar, Tanzania (Unpublished master's thesis). Wesleyan University, Middletown, Connecticut, U.S.A.

Caliendo, M., Kopeinig, S. (2008). Some practical guidance for the implementation of propensity score matching. J. Econ. Surv., 22(1), 31-72.

Chagwiza, C., Muradian, R., Ruben, R. (2016). Cooperative membership and dairy performance among smallholders in Ethiopia. Food Polic., 59, 165-173.
Cheng, E. (2006). The Demand for Micro-Credit as a Determinant for Microfinance Outreach - Evidence from China". Paper presented at ACESA 2006 Emerging China: Internal Challenges and Global Implications, Victoria University, Melbourne, July, 13-14.

Chikaire, J.U., Ani, A.O., Atoma, C.N., Tijjani, A.R. (2015). Extension services for effective agricultural risk management in Orlu agricultural zone of Imo State, Nigeria. Schol. J. Agric. Vet. Sci., 2(1A), 1-8.

Crepon, B., Duflo, E., Periente, W. (2014). Estimating the impact of Microcredit on those who take it up: Evidence from a randomized experience in Morocco. National Bureau of Economic Research, U.S.A.

Diagne, A., Zeller, M. (2001). Access to Credit and Its Impact in Malawi. Research Report No. 116. Washington D.C., USA: International Food Policy Research Institute (IFPRI).

Duffour, K. (2011). Budget statement and economic policy of the government of Ghana. P.49. Ghana.

Duniya, K.P., Adinah, I.I. (2015). Probit analysis of cotton farmers' accessibility to credit in northern Guinea savannah of Nigeria. Asian J. Agric. Ext., Econ. Soc., 4, 296-301.

Essien, U.A., Arene, C.J., Nweze, N.J. (2013). An investigation into credit receipt and enterprise performance among agro small scale agro based enterprises in the Niger Delta Region of Nigeria? Int. J. Agric. Manag. Dev., 3(4), 245-258.

Estruk, O., Oren, M. (2014). Impact of household socio-economic factors on food security: Case of Adana, Turkey. Pakistan J. Nutr., 13(1), 1-6.

FAO (2005). FAO Warns World Cannot Afford Hunger. Retrieved from: www.fao.org./fao newsroom.

FAO (2008). The state of food and agriculture in Asia and the Pacific Asia and the Pacific Food Situation Update. Rome: Food and Agriculture Organization of the United State.

FAO (2010). The state of food insecurity in the World. Rome: Food and Agriculture Organization of the United Nations.

FAO (2012). The state of food insecurity in the World. The 2012 edition. Retrieved from: www.fao.org/ docrep/016/13027e00.htm

FAO (2013). The state of food insecurity in the World. The multiple dimensions of food security. Rome: Food and Agriculture Organization of the United Nations.

Fakiyesi, O.M. (2001). Encouraging Growth to reduce Poverty in Nigeria. Nig. Econ. Fin. Rev., 39(2), 61-91.

Fawehinmi, O.A., Adeniyi, O.R. (2014). Gender dimensions of food security status of households in Oyo State, Nigeria. Glob. J. Hum. Sci., 14(1), 7-15.

Francesconi, G.N., Ruben, R. (2012). The hidden impact of cooperative membership on quality management: A case 
study from the dairy belt of Addis Ababa. J. Ent. Org. Div., $1(1), 85-103$.

Gibremichael, B.A. (2014). The role of agricultural coops in promoting food security and rural women's empowerment in Eastern Tigray Region, Ethiopia. J. Dev. Coun. Stud., 4(11), 96-109.

Hamad, R., Lia, C., Fernald, L. (2010). Microcredit participation and nutrition outcomes among women in Peru. World J. Agric. Sci., 9(8), 56-59.

Hazarika, G., Guha-Khasnobis, B. (2008). Household Access to Microcredit and Children's Food Security in Rural Malawi: A Gender Perspective. Washington D.C.: IFPRI.

Ibok, O.W. (2012). Analysis of food security and productivity of urban food crop farmers in Cross River State. Unpublished master's thesis. University of Calabar, Nigeria.

Ibrahim, S.S., Aliero, H.M. (2012). An analysis of farmers' access to formal credit in the rural areas of Nigeria. Afr. J. Agric. Res., 7, 6249-6253.

Idrisa, Y.I., Gwary, M.M., Shehu, H. (2008). Analysis of food security status among farming households in Jere local government of Borno State, Nigeria. J. Tropic. Agric. Food, Env. Ext., 7(3), 199-205.

Ijaiya, G.T., Abdulraheem, A. (2000). Commercial banks credits to the agricultural sector and poverty reduction in Nigeria: A calibration analysis. Nig. J. Agribiz. Rural Dev., 1(1), 143-157.

Khan, R.E.A., Hussain, T. (2011). Demand for formal and informal credit in agriculture: a case study of cotton growers in Bahawalpur. Interdis. J. Cont. Res. Bus., 2(10), 1-7.

Lecoutere, E. (2017). The impact of agricultural co-operatives on women"s empowerment: Evidence from Uganda. J. Coop. Org. Manag., 5, 14-27.

Ma, W., Abdulai, A. (2016). Does cooperative membership improve household welfare? Evidence from apple farmers in China. Food Pol., 58, 94-102.

Ma, W., Abdulai, A., Goetz, R. (2018). Agricultural cooperatives and investment in organic soil amendments and chemical fertilizer in China. Am. J. Agric. Econ,. 100, $502-520$

Mohamen, I. (2003). Access to formal and quasi-formal credit by small holder farmers and artisanal fishermen. A case of Zanzibar. Research Report on poverty alleviation. No. 03.6.

Mojo, D., Fischer, C., Degefa, T. (2017). The determinants and economic impacts of membership in coffee farmer cooperatives: recent evidence from rural Ethiopia. J. Rural Stud., 50, 84-94.

Nuryartono, N. (2007). Credit rationing of farm households and agricultural production: empirical evidence in the rural areas of central Sulawesi, Indonesia. J. Manag. Agribus., $4,15-21$.
Nwaru, J.C., Essien, U.A., Onuoha, R.E. (2011). Determinants of informal credit demand and supply among food crop farmers in Akwa Ibom State, Nigeria. J. Rural Com. Dev., 6(1), 129-139.

Odemenem, I.U., Obinne, C.P.O. (2010). Assessing the factors influencing the utilization of improved cereal crop production technologies by small scale farmers in Nigeria. Ind. J. Sci. Tech., 3(1), 180-183.

Okurut, F.N. (2006). Access to credit by the poor in South Africa: Evidence from household survey data 1995 and 2000. Stellenbosch Economic Working Paper: 13/06.

Olawale, S. (2018). Nigeria poverty statistics and poverty rate in Nigeria. Retrieved Aug 2020 from: http://www.naijaquest.com/Nigeria poverty statistics/

Ololade, R.A., Olagunju, F.I. (2013). Determinants of access to credit among rural farmers in Oyo State, Nigeria. Global J. Sci. Frontier Res. Agric. Vet. Sci., 13(2), 16-22.

Oluyole, K.A., Taiwo, O. (2016). Socio-economic Variables and Food Security Status of Cocoa Farming Households in Ondo State, Nigeria. Asian J. Agric. Ext. Econ. Soc., 9(1), 1-7.

Orewa, S.I., Iyangbe, C.O. (2009). The food security profile among the rural and low-income urban dweller in Nigeria. Am-Eurasia. J. Sci. Res., 4(4), 302-307.

Oxfam Canada (2012). Behind the brands - Cocoa Case Studies. Retrieved from: https://42kgab3z3i7s3rm1xf48rq44wpengine.netdna-ssl.com/wp-content/uploads/2013/03/ btb-oxfam-cocoa-case-studies.pdf

Oyedele, G.A., Akintola, J.O., Rahji, M.A.Y., Omonona, B.T. (2009). Credit constrained condition of farm households and profitability of agricultural production in Nigerian agriculture. Agric. J., 4, 192-201.

Robins, J., Sued, M., Lei-Gomez, Q., Rotnitzky, A. (2007). Comment: performance of double robust estimators when "inverse probability" weights are highly variable. Stat. Sci. 544e559.

Rosenbaum, P.R. (2002). Observational studies. New York: Springer

Rosenbaum, P.R., Rubin, D.B. (1983). The central role of the propensity score in observational studies for causal effects. Biometrika, 70, 41-55.

Sebopetji, T.O., Belete, A. (2009). An application of probit analysis to factors affecting small-scale farmers' decision to take credit: a case study of the Greater Letaba Local Municipality in South Africa. Afr. J. Agric. Res., 4, 718-723.

Shiferaw, B., Kassie, M., Jaleta, M., Yirga, C., (2014). Adoption of improved wheat varieties and impacts on household food security in Ethiopia. Food Pol., 44, 272-284, http://dx.doi.org/10.1016/j.foodpol.2013.09.012 
Kehinde, A. D., Kehinde, M. A. (2020). The impact of credit access and cooperative membership on food security of rural households in south-western Nigeria. J. Agribus. Rural Dev., 3(57), 255-268. http://dx.doi.org/10.17306/J.JARD.2020.01337

Tasie, C.M., Wonodi, J.O., Wariboko, O.N., Ajuru, I. (2012). The effect of microcredit delivery on rural crop farmers in Rivers State, Nigeria. J. Voc. Edu. Tech., 9(2).

Tefera, D.A., Bijman, J., Slingerland, M.A. (2016). Agricultural co-operatives in Ethiopia: evolution, functions and impact. J. Int. Dev., 29(4), 431-453. doi: 10.1002/jid.3240

Ugbajah, M., Ugwumba, C. (2013). Analysis of Micro Credit as a Veritable Tool for Poverty Reduction among Rural Farmers in Anambra State, Nigeria. Disc. J. Agric. Food Sci., 1(10), 152-159.

Verhofstadt, E., Maertens, M. (2015). Can agricultural cooperatives reduce poverty? Heterogeneous impact of coopera- tive membership on farmers' welfare in Rwanda. Appl. Econ. Pers. Pol., 37, 86-106.

Wooldridge, J.M. (2010). Econometric Analysis of Cross Section and Panel Data. Cambridge: MIT Press.

Wossen, T., Abdoulaye, T., Alene, A., Haile, M.G., Feleke, S., Olanrewaju, A., Manyong, V. (2017). Impacts of extension access and cooperative membership on technology adoption and household welfare. J. Rural Stud., 54, 223-233.

Zeng, D., Alwang, J., Norton, G.W., Shiferaw, B., Jaleta, M., Yirga, C. (2015). Ex post impacts of improved maize varieties on poverty in rural Ethiopia. Agric. Econ., 46(4), 515-526. doi: 10.1111/agec. 12178 